\title{
KAJIAN PENGGUNAAN TEPUNG UWI PUTIH KULIT COKELAT (Dioscorea rotundata) DALAM PEMBUATAN MINUMAN SINBIOTIK TERHADAP KARAKTERISTIK FISIKOKIMIA, SENSORI, DAN TOTAL BAKTERI PROBIOTIK
}

\author{
STUDY OF WHITE YAM FLOUR (Dioscorea rotundata) USING IN PRODUCING OF \\ SYNBIOTIC BEVERAGES TOWARD PHYSICOCHEMICAL CHARACTERISTICS \\ SENSORY, AND TOTAL PROBIOTIC BACTERIA
}

\author{
Titin Andriyani A. ${ }^{1)}$, Rohula Utami'), Esti Widowati ${ }^{1)}$ \\ 1) Program Studi Ilmu dan Teknologi Pangan Fakultas Pertanian Universitas Sebelas Maret \\ email: inayirdna@gmail.com
}

\begin{abstract}
The aim of this study was to determine the addition influence of concentration white yam flour in synbiotic beverage to $\mathrm{pH}$ value, viscosity, lactic acid levels, the characteristic of sensory, and total probiotic bacteria. The study consisted of two main phases, making white yam's flour and making synbiotic beverage. The research had been performed using Completely Randomized Design (CRD) with one factor i.e. the concentration of white yam flour with skim milk. Data analyzed were statistically using one-way ANOVA at $\alpha$ level of 0.05 and followed with Duncan Multiple Range Test (DMRT) at a level of 0.05. Results obtained showed in differences concentration of white yam flour have an difference influence on the $\mathrm{pH}$ value, viscosity value, lactic acid levels, the value of sensory, and total probiotic bacteria. Lowest $\mathrm{pH}$ value $(3,68)$, the highest levels of lactic acid $(0,60 \%)$, and the largest total probiotic bacteria $(9,39 \log \mathrm{cfu} / \mathrm{ml})$ obtained from the addition of $2.5 \%$ flour and $7.5 \%$ skim milk. The biggest viscosity values obtained from the addition of $10 \%$ flour and $0 \%$ skim milk of $10,92 \mathrm{mPas}$. Based on analysis of sensory the additional $7.5 \%$ flour and $2.5 \%$ skim milk has the best value among the four sensory other samples based on parameters of color $(2,78)$, thickness $(2,41)$ and overall $(2,85)$.
\end{abstract}

Keyword: inulin, prebiotic, probiotic, synbiotic, white yam.

ABSTRAK

Tujuan dari penelitian ini untuk mengetahui pengaruh konsentrasi tepung uwi putih kulit cokelat terhadap nilai $\mathrm{pH}$, viskositas, kadar asam laktat, karakteristik sensori, dan total bakteri probiotik pada minuman sinbiotik uwi putih kulit cokelat. Penelitian ini terdiri dari dua tahap utama yaitu pembutatan tepung uwi putih kulit cokelat dan pembuatan minuman sinbiotik uwi putih kulit cokelat. Rancangan percobaan adalah Rancangan Acak Lengkap (RAL) dengan satu faktor yaitu kombinasi tepung uwi putih kulit cokelat. Untuk melihat beda nyata antar perlakuan dianalisis secara statistik menggunakan oneway ANOVA pada taraf $\alpha 0,05$ dilanjutkan dengan menggunakan uji Duncan Multiple Range Test (DMRT) pada taraf $\alpha 0,05$. Perbedaan konsentrasi tepung uwi putih kulit cokelat memberikan pengaruh yang berbeda terhadap nilai $\mathrm{pH}$, nilai viskositas, kadar asam laktat, nilai sensori, dan total bakteri probiotik. Nilai $\mathrm{pH}$ terendah $(3,68)$, kadar asam laktat tertinggi $(0,60 \%)$, dan total bakteri probiotik terbesar $(9,39 \log \mathrm{cfu} / \mathrm{ml})$ didapatkan dari penambahan 2,5\% tepung uwi putih kulit cokelat dan $7,5 \%$ susu skim. Nilai viskositas terbesar didapatkan dari penambahan $10 \%$ tepung uwi putih kulit cokelat dan $0 \%$ susu skim yaitu $10,92 \mathrm{mPas}$. Berdasarkan analisis sensori penambahan tepung uwi putih kulit cokelat 7,5\% dan susu skim 2,5\% memiliki nilai sensori paling baik diantara keempat sampel lainnya berdasarkan parameter warna $(2,78)$, kekentalan $(2,41)$ dan overall $(2,85)$.

Kata kunci: inulin, prebiotik, probiotik, sinbiotik, uwi putih kulit cokelat.

\section{PENDAHULUAN}

Wild Yam (Dioscorea spp.) yang di Indonesia dikenal dengan nama uwi (varietas umbi uwi) merupakan varietas umbi-umbian yang banyak tumbuh di Indonesia, namun kurang dimanfaatkan oleh masyarakat. Berdasarkan penelitian sebelumnya telah dilaporkan bahwa uwi memiliki kandungan inulin yang dapat dimanfaatkan sebagai prebiotik. Salah satu dari uwi yang menghasilkan inulin adalah uwi putih kulit cokelat (Dioscorea rotundata). Uwi putih berkulit coklat memiliki kandungan inulin cukup tinggi yaitu 13,723\% (Yuniar, 2010). Inulin dalam uwi putih kulit cokelat berpotensi untuk diaplikasikan ke dalam produk pangan sehingga dapat menghasilkan pangan fungsional.

Inulin dalam uwi putih kulit cokelat dapat dimanfaatkan sebagai prebiotik. Seperti yang dijelaskan Praja (2011) bahwa inulin tergolong senyawa yang digolongkan 
dalam prebiotik. Sifat fungsional inulin sebagai serat makanan dapat larut (soluble dietary fiber) atau yang biasa disebut digestive fibersangat bermanfaat bagi pencernaan. Inulin bersifat larut dalam air dan mampu mencapai usus besar tanpa mengalami perubahan struktur. Di dalam usus besar, sebagian besar inulin difermentasi menjadi asam-asam lemak rantai pendek. Hal ini menyebabkan penurunan $\mathrm{pH}$ kolon yang mengakibatkan terhambatnya pertumbuhan bakteri patogen (Sardesai, 2003).

Istilah prebiotik didefinisikan sebagai bahan makanan yang bersifat nondigestible (tidak dapat dicerna) yang memiliki efek menguntungkan dengan menstimulasi pertumbuhan bakteri baik dalam saluran pencernaan manusia. Sedangkan pengertian istilah probiotik merupakan mikroorganisme hidup yang mempunyai pengaruh menguntungkan pada kesehatan manusia. Perpaduan antara produk probiotik dan prebiotik disebut sinbiotik (Praja, 2011). Di pasaran kini mulai banyak bermunculan produk sinbiotik yang merupakan kombinasi dari prebiotik dengan probiotik. Keuntungan dari kombinasi prebiotik dengan probiotik adalah meningkatkan daya hidup dari probiotik itu sendiri karena substrat spesifik telah tersedia untuk fermentasi. Selain itu, konsumen akan mendapatkan manfaat ganda dari keduanya.

Aplikasi konsep sinbiotik sering ditemukan dalam produk-produk minuman fermentasi. Minuman fermentasi sering menggunakan Bakteri Asam Laktat (BAL) dalam proses fermentasinya. Proses fermentasi tersebut memberikan nilai tambah dari segi gizi dan citarasa pada produk yang dihasilkan. Ada beberapa penelitian mengenai produk-produk fermentasi sinbiotik yang telah dilakukan sebelumnya, seperti penelitian minuman sinbiotik pisang kepok (Umam, 2012), minuman sinbiotik ubi jalar ungu (Ainovi, 2010), minuman sinbiotik ekstrak cincau hijau (Nurdin dan Rizal, 2008), dan yogurt sinbiotik garut (Rosa, 2010).

Berdasarkan latar belakang tersebut akan dilakukan penelitian mengenai pemanfaatan tepung uwi putih kulit cokelat sebagai sumber prebiotik dalam pembuatan minuman fermentasi sinbiotik. Bakteri probiotik yang digunakan adalah bakteri Lactobacillus acidhopillus dan Bifidobacterium longum. Pompei et al., (2008), menyebutkan bahwa bakteri Bifidobacterium adolesentis, Bifidobacterium infantis, Bifidobacterium breve, Bifidobacterium longum, Lactobacilus plantarum, Lactobacilus rhamnosus, Lactobacilus reuteri, dan Lactobacilus delbruechii mampu meningkat pertumbuhannya dengan penambahan inulin.

Penelitian ini bertujuan untuk mengetahui pengaruh penggunaan tepung uwi putih kulit cokelat (Dioscorea rotundata) terhadap karakter fisikokimia yang meliputi $\mathrm{pH}$, kadar asam laktat dan viskositas, karakteristik sensori, dan total bakteri probiotik minuman sinbiotik.

\section{METODE PENELITIAN}

\section{Bahan}

Bahan yang digunakan dalam penelitian ini adalah uwi putih kulit cokelat yang digunakan diperoleh dari desa Demangan, Sambi, Boyolali, susu skim bubuk yang diperoleh dari Pasar Gede, starter dalam bentuk kultur murni Lactobacillus acidophilus IFO 13951 dan Bifidobacterium longum ATCC 15707 diperoleh dari Food and Nutrition Culture Collection (FNCC) Universitas Gadjah Mada. Selain itu juga digunakan bahan untuk analisis antara lain aquades, Natrium Metabisulfit, alkohol 70\%, de Mann Rogosa and Sharpe (MRS) Broth (OXOID), Bacto Agar (OXOID), de Mann Rogosa and Sharpe Agar (MRSA), asam oksalat dihidrat $\left(\mathrm{C}_{2} \mathrm{H}_{2} \mathrm{O}_{4} .2 \mathrm{H}_{2} \mathrm{O}\right)(\mathrm{MERCK})$, Phenolphthalein (PP) $1 \% \quad(\mathrm{pH} \quad 8,3-10), \quad \mathrm{NaOH} \quad 0,01 \quad \mathrm{~N}$ (MERCK), dan de Mann Rogosa and Sharpe Agar (MRSA) (MERCK).

\section{Tahapan Penelitian}

\section{Pembiakan Bakteri}

Pembiakan bakteri dimulai dengan peremajaan kultur setelah didapatkan kultur murni Lactobacillus acidophillus IFO 13951 dan Bifidobacterium longum ATCC 15707. Peremajaan bakteri dilakukan dengan 
menggunakan media MRS broth (cair) kemudian diinkubasi suhu $37^{\circ} \mathrm{C}$ selama 24 jam dan disimpan suhu $4^{\circ} \mathrm{C}$.

\section{Pembuatan Starter}

Setelah pembiakan kultur pada media MRS broth (cair) kemudian kultur diinokulasi dalam media susu skim $10 \%$ (b/v) dan diinkubasi selama 12 jam. Hasil inkubasi ini disebut starter induk, dan selanjutnya dari starter induk diinokulasikan ke dalam media susu skim $10 \%$ (b/v) dan diinkubasi selama 12 jam. Selanjutnya hasil inkubasi ini disebut starter kerja yang digunakan sebagai starter dalam pembuatan minuman sinbiotik.

\section{Pembuatan Tepung Uwi Putih Kulit Cokelat}

Jenis bahan baku yang digunakan adalah uwi putih kulit cokelat dengan kriteria : tua, warnanya cokelat tua dan tidak pucat, segar, tidak cacat, tidak busuk, kulit tidak keriput, dan tidak terdapat serangga didalamnya. Selanjutnya proses pencucian supaya pada proses pengupasan, tanah atau kotoran tidak melekat pada tangan yang akan berpengaruh pada umbi yang dikupas. Blanching dengan cara umbi direndam pada air yang bersuhu $80^{\circ} \mathrm{C}$ selama 30 detik. Setelah perebusan dilakukan proses pendinginan uwi putih kulit cokelat, dengan cara dicelupkan ke air dingin yang mengalir. Pengupasan dilakukan dalam kondisi uwi putih kulit cokelat terendam air yang bertujuan untuk menghindari kontak dengan udara supaya tidak terjadi pencoklatan enzimatis. Uwi putih kulit cokelat yang telah bersih kemudian diiris dengan ketebalan \pm 10 - $20 \mathrm{~mm}$. Perendaman irisan uwi menggunakan Natrium metabisulfit $\left(\mathrm{Na}_{2} \mathrm{~S}_{2} \mathrm{O}_{5}\right)$ dengan konsentrasi $0,3 \%$ (Widiyowati, 2007) selama 30 menit. Uwi putih kulit cokelat ditata pada rak - rak pengeringan. Pengeringan dilakukan dengan menggunakan cabinet dryer pada suhu 55$60^{\circ} \mathrm{C}$ selama \pm 8 jam. Uwi putih kulit cokelat yang telah kering kemudian digiling supaya menghasilkan tepung yang halus, kemudian diayak dengan ayakan 80 mesh.

\section{Pembuatan Minuman Sinbiotik}

Pembuatan minuman sinbiotik diawali dengan melarutkan tepung uwi putih kulit cokelat dan susu skim dalam air. Penambahan tepung uwi putih kulit cokelat dengan konsentrasi $0 \% ; 2,5 \% ; 5 \% ; 7,5 \%$; dan $10 \%(\mathrm{~b} / \mathrm{v})$. Penambahan tepung susu skim dengan konsentrasi $10 \% ; 27,5 \% ; 5 \%$; $2,5 \%$; dan $0 \%(\mathrm{~b} / \mathrm{v})$. Kemudian sampel minuman sinbiotik dipasteurisasi pada suhu $85^{\circ} \mathrm{C}$ selama 30 menit. Selanjutnya didinginkan hingga suhu $45^{\circ} \mathrm{C}$ dan starter campuran yang terdiri dari L. acidophilus dan B. longum diinokulasikan dengan perbandingan starter 1:1 sebanyak 3\% (v/v) $\left(10^{8} \mathrm{CFU} / \mathrm{ml}\right)$ secara aseptis. Setelah inokulasi, kemudian diinkubasi pada suhu $37^{\circ} \mathrm{C}$ selama 12 jam.

Penelitian ini menggunakan Rancangan Acak Lengkap (RAL) dengan faktor konsentrasi tepung uwi putih kulit cokelat masing-masing perlakuan dilakukan dua kali ulangan sampel dan dua kali ulangan analisis. Data hasil penelitian ini selanjutnya dianalisis secara statistik menggunakan dengan menggunakan One Way ANOVA melalui program SPSS 16.0. Jika terdapat perbedaan maka dilanjutkan dengan Duncan Multiple Range Test (DMRT) pada taraf signifikansi 5\%.

Analisis karakteristik fisikokimia meliputi analisis derajat keasaman $(\mathrm{pH})$ dengan pHmeter (Hadiwiyoto, 1994), kadar asam laktat dengan Titrimetri $\mathrm{NaOH} 0,1 \mathrm{~N}$ (Hadiwiyoto, 1994), viskositas dengan Falling Ball Viscometer (Hadiwiyoto, 1994), analisis karakteristik sensori dengan Uji Skoring (Kartika dkk, 1988), dan analisis mikrobiologis (total bakteri probiotik) dengan Total Plate Count (Fardiaz, 1993).

\section{HASIL DAN PEMBAHASAN}

\section{Derajat Keasaman (pH)}

Formulasi F2 (2,5\% tepung uwi putih kulit cokelat : 7,5\% susu skim) menghasilkan kondisi $\mathrm{pH}$ yang paling asam dibadingkan dengan formulasi lainnya. Hal 
Tabel 1. Hasil Analisis pH, Viskositas, Kadar Asam Laktat dan Total Bakteri Probiotik Minuman Sinbiotik Tepung Uwi Putih Kulit Cokelat

\begin{tabular}{lcccc}
\hline \multicolumn{1}{c}{ Sampel } & $\mathrm{pH}$ & $\begin{array}{c}\text { Viskositas } \\
(\mathrm{mPas})\end{array}$ & $\begin{array}{c}\text { Kadar asam } \\
\text { laktat }(\%)\end{array}$ & $\begin{array}{c}\text { Total Bakteri } \\
(\log \mathrm{cfu} / \mathrm{ml})\end{array}$ \\
\hline F1 (0\% tepung : 10\% skim) & $3,99^{\mathrm{b}}$ & $1,41^{\mathrm{a}}$ & $0,55^{\mathrm{d}}$ & $9,34^{\mathrm{d}}$ \\
F2 (2,5\% tepung : 7,5\% skim) & $\mathbf{3 , 6 8}^{\mathrm{a}}$ & $2,10^{\mathrm{a}}$ & $\mathbf{0 , 6 0}^{\mathrm{e}}$ & $\mathbf{9 , 3 9}^{\mathrm{e}}$ \\
F3 (5\% tepung : 5\% skim) & $4,13^{\mathrm{b}}$ & $3,89^{\mathrm{b}}$ & $0,50^{\mathrm{c}}$ & $9,07^{\mathrm{c}}$ \\
F4 (7,5\% tepung : 2,5\% skim) & $4,63^{\mathrm{c}}$ & $6,51^{\mathrm{c}}$ & $0,43^{\mathrm{b}}$ & $9,02^{\mathrm{b}}$ \\
F5 (10\% tepung : 0\% skim) & $5,14^{\mathrm{d}}$ & $\mathbf{1 0 , 9 2}^{\mathrm{d}}$ & $0,36^{\mathrm{a}}$ & $8,98^{\mathrm{a}}$
\end{tabular}

Keterangan : Angka yang diikuti huruf yang sama menunjukkan tidak berbeda nyata pada taraf signifikansi $\alpha$ 0,05

ini dimungkinkan pada formulasi ini merupakan formulasi optimal dari minuman sinbiotik uwi putih kulit cokelat yang dapat difermentasi oleh bakteri probiotik. Pada formulasi tersebut terdapat ketersediaan nutrisi yang melimpah untuk bakteri probiotik yaitu laktosa pada susu skim, dan inulin dalam tepung uwi putih kulit cokelat sebagai substrat spesifik bakteri probiotik. Prebiotik inulin yang terdapat dalam tepung uwi putih kulit cokelat akan mampu menstimulasi pertumbuhan dari bakteri probiotik yang digunakan. Sehingga meningkatkanjumlah bakteri probiotik yang akan menyebabkan produksi asam meningkat dan terjadi penurunan $\mathrm{pH}$. Menurut Groff and Gropper, (2000) inulin akan difermentasi oleh bakteri probiotik dengan menghasilkan asam laktat serta asam-asam lemak rantai pendek (asetat, butirat, propionat). Produk dari bakteri tersebut akan menurunkan $\mathrm{pH}$ yoghurt. Berdasarkan hasil analisis statistik nilai $\mathrm{pH}$, dinyatakan bahwa formulasi tepung uwi putih kulit cokelat dan susu skim dalam pembuatan minuman sinbiotik menunjukkan berbeda nyata $(p<0,05)$. Hal ini berarti perbedaan konsentrasi tepung uwi putih kulit cokelat menunjukkan pengaruh yang berbeda nyata terhadap nilai $\mathrm{pH}$ minuman sinbiotik.

\section{Viskositas}

Nilai viskositas yang terbesar pada F5 (10\% tepung uwi putih kulit cokelat : 0 \% susu skim) sebesar 10,92 mPas (Tabel 1). Pada minuman sinbiotik uwi putih kulit cokelat nilai viskositas semakin besar seiring dengan semakin banyak tepung uwi putih kulit cokelat yang ditambahkan. Hal ini dikarenakan semakin banyak jumlah tepung uwi putih kulit cokelat yang ditambahkan konsentrasi susu skim akan semakin berkurang. Sehingga faktor yang paling mempengaruhi nilai viskositas adalah adanya gelatinisasi selama proses pasteurisasi. Tingginya kandungan pati dalam minuman sinbiotik uwi putih kulit cokelat berpengaruh terhadap nilai viskositas. Penelitian Alinnor and Akalezi (2010) menyatakan bahwa karbohidrat pada uwi putih kulit cokelat 40,61 \% (\% berat kering), yang didukung penelitian Mcanuff et al., (2005) yang menyatakan karbohidrat uwi putih kulit cokelat sebesar 820,1 g/ kg bahan (berat kering). Pati akan mengalami gelatinisasi selama proses pasteurisasi. pati pada suhu antara $55^{\circ} \mathrm{C}$ sampai $65^{\circ} \mathrm{C}$. Apabila granula pati dipanaskan di dalam air, maka ikatan hidrogen akan terputus, dan air masuk ke dalam granula pati. Air yang masuk akan membentuk ikatan hidrogen dengan amilosa dan amilopektin yang menyebabkan terjadinya pembengkakan granula pati. Ukuran granula akan meningkat sampai batas tertentu sebelum akhirnya granula pati pecah. Pecahnya granula menyebabkan bagian amilosa dan amilopektin berdifusi keluar (Suhardi, 1991).

\section{Kadar Asam Laktat}

Kadar asam laktat sampel minuman sinbiotik uwi putih kulit cokelat formulasi F2 $(2,5 \%$ tepung uwi putih kulit cokelat : $7,5 \%$ susu skim) memiliki kadar asam laktat yang paling tinggi (Tabel 1). Hal ini dikarenakan adanya sumber karbon optimal dari susu skim dan substrat spesifik dari tepung uwi putih kulit cokelat. Sumber 
Tabel 2. Hasil Analisis Sensori Minuma Sinbiotik Tepung Uwi Putih Kulit Cokelat

\begin{tabular}{llllll}
\hline \multicolumn{1}{c}{ Sampel* } & \multicolumn{5}{c}{ Analisis Sensori } \\
\cline { 2 - 6 } & Warna & Aroma & Rasa & kekentalan & overall \\
\hline F1 (0\% tepung : 10\% skim) & $3,37^{\mathrm{a}}$ & $3,41^{\mathrm{a}}$ & $3,67^{\mathrm{b}}$ & $3,11^{\mathrm{b}}$ & $3,63^{\mathrm{b}}$ \\
F2 (2,5\% tepung : 7,5\% skim) & $2,96^{\mathrm{a}}$ & $\mathbf{2 , 9 3}^{\mathrm{a}}$ & $3,11^{\mathrm{ab}}$ & $2,56^{\mathrm{a}}$ & $3,07^{\mathrm{ab}}$ \\
F3 (5\% tepung : 5\% skim) & $2,81^{\mathrm{a}}$ & $3,30^{\mathrm{a}}$ & $3,52^{\mathrm{b}}$ & $2,44^{\mathrm{a}}$ & $3,19^{\mathrm{ab}}$ \\
F4 (7,5\% tepung : 2,5\% skim) & $\mathbf{2 , 7 8 ^ { \mathrm { a } }}$ & $3,33^{\mathrm{a}}$ & $3,07^{\mathrm{ab}}$ & $\mathbf{2 , 4 1}$ & $\mathbf{2 , 8 5}^{\mathrm{a}}$ \\
F5 (10\% tepung : 0\% skim) & $3,30^{\mathrm{a}}$ & $3,63^{\mathrm{a}}$ & $\mathbf{2 , 7 4 ^ { \mathrm { a } }}$ & $4,11^{\mathrm{c}}$ & $3,37^{\mathrm{ab}}$ \\
\hline
\end{tabular}

Keterangan : 1 = sangat suka; $2=$ suka; $3=$ netral; $4=$ tidak suka; $5=$ sangat tidak suka.

Angka yang diikuti huruf yang sama menunjukkan tidak berbeda nyata pada taraf signifikansi $\alpha 0,05$

energi yang digunakan oleh bakteri dalam menghasilkan asam laktat selain dari susu skim, juga diperoleh dari tepung uwi putih kulit cokelat karena pada tepung uwi putih kulit cokelat mengandung inulin dan karbohidrat yang dapat digunakan sebagai sumber karbon.

Inulin dihubungkan oleh rantai yang tidak dapat dihidrolisis oleh sistem penernaan manusia menjadi monosakarida seperti fruktosa dan glukosa, inilah yang menyebabkan inulin menjadi tidak dapat dicerna. Tetapi inulin dapat dihidrolisis dan difermentasi olah bakteri probiotik menjadi asam lemak rantai pendek (short chain fatty acid) (Loo, 2006). Inulin tergolong oligosakarida yang memiliki derajat polimerisasi 2- 60 (Roberfroid, 2005).

Formulasi tepung uwi putih kulit cokelat dan susu skim dalam pembuatan minuman sinbiotik memberikan pengaruh berbeda nyata $(\mathrm{p}<0,05)$ pada kadar asam laktat minuman fermentasi sinbiotik. Hal ini berarti perbedaan konsentrasi tepung uwi putih kulit cokelat dan susu skim akan menghasilkan kadar asam laktat yang berbeda pada setiap formulasinya. Hasil penelitian ini sama seperti penelitian yang dilakukan oleh Ma'rifah (2008) yang menyatakan bahwa yoghurt sinbiotik pati singkong modifikasi dengan konsentrasi $2,5 \%$ memberikan nilai total asam tertitrasi lebih besar dibandingkan pada konsentrasi $5 \%$ dengan penambahan susu skim yang sama yaitu $10 \%$.

\section{Karakteristik Sensori}

\section{Warna}

Warna memberikan indikasi perubahan kimia dalam makanan seperti pencoklatan dan karamelisasi (deMan, 1999). Berdasarkan data pada Tabel 2 untuk parameter warna, perbedaan konsentrasi tepung uwi putih kulit cokelat dan susu skim tidak berbeda nyata $(p<0,05)$. Hal ini menunjukkan bahwa perbedaan konsentrasi tepung uwi putih kulit cokelat dan susu skim tidak memberikan pengaruh yang signifikan terhadap parameter warna. Berdasarkan analisis sensori, panelis lebih menyukai sampel F4 yaitu sampel dengan formulasi 7,5\% tepung uwi putih kulit cokelat : 2,5\% susu skim. Warna minuman sinbiotik putih kecoklatan dikarenakan bahan baku yang digunakan adalah susu skim dan tepung uwi putih kulit cokelat. Sedangkan sampel F1 dengan formulasi $0 \%$ tepung uwi putih kulit cokelat : $10 \%$ susu skim memiliki warna yang paling tidak disukai panelis.

\section{Aroma}

Kebanyakan komponen flavor pada yoghurt terbentuk dari fermentasi laktosa oleh bakteri asam laktat. Berdasarkan data pada Tabel 2 untuk parameter aroma, perbedaan konsentrasi tepung uwi putih kulit cokelat dan susu skim tidak berbeda nyata $(\mathrm{p}<0,05)$. Hal ini menunjukkan bahwa perbedaan konsentrasi tepung uwi putih kulit cokelat dan susu skim tidak memberikan pengaruh yang signifikan terhadap parameter aroma. Berdasarkan data pada Tabel 2 sampel yang memiliki nilai sensori paling baik berdasar parameter aroma adalah sampel F2 dengan formulasi 2,5\% tepung uwi putih kulit cokelat : 7,5\% susu skim. Sedangkan sampel yang memiliki nilai sensori paling rendah dari parameter aroma adalah sampel F5 dengan formulasi $10 \%$ tepung uwi putih kulit cokelat : $0 \%$ susu skim. Hal ini berbanding lurus dengan 
kadar asam laktat pada Tabel 1 yaitu nilai kadar asam laktat untuk sampel F2 (2,5\% tepung uwi putih kulit cokelat : 7,5\% susu skim) adalah yang paling besar $(0,60)$. Banyaknya produksi asam laktat akan mempengaruhi aroma nimuman sinbiotik. Semakin besar asam laktat yang dihasilkan maka aroma asam yang dihasilkan akan semakin kuat.

\section{Rasa}

Berdasarkan parameter rasa panelis cenderung menyukai sampel yang tidak terlalu asam. Sampel yang memiliki nilai sensori paling disukai oleh panelis adalah sampel F5 dengan formulasi 10\% tepung uwi putih kulit cokelat : $0 \%$ susu skim. Sedangkan sampel dengan parameter rasa yang terendah menurut panelis adalah sampel F1 dengan formulasi $0 \%$ tepung uwi putih kulit cokelat : $10 \%$ susu skim. Berdasarkan parameter rasa dapat disimpulkan panelis lebih menyukai sampel yang memiliki nilai asam rendah yaitu sampel F5 yang merupakan sampel dengan nilai $\mathrm{pH}$ paling tinggi yaitu 5,14, dan kadar asam laktat paling rendah yaitu 0,36.

\section{Kekentalan}

Sampel yang memiliki nilai sensori dari parameter kekentalan terbaik menurut panelis adalah sampel F4 dengan formulasi 7,5 \% tepung uwi putih kulit cokelat : 2,5\% susu skim. Sedangkan sampel yang memiliki nilai terendah dari parameter kekentalan menurut panelis adalah sampel F5 dengan formulasi $10 \%$ tepung uwi putih kulit cokelat : $0 \%$ susu skim.

\section{Overall}

Sampel yang memiliki nilai tertinggi berdasarkan parameter overall menurut panelis adalah sampel F4 dengan formulasi 7,5\% tepung uwi putih kulit cokelat : 2,5\% susu skim. Sedangkan sampel yang memiliki nilai terendah berdasarkan parameter overall menurut panelis adalah sampel F1 dengan formulasi $0 \%$ tepung uwi putih kulit cokelat : $10 \%$ susu skim. Berdasarkan penilaian tersebut dapat disimpulkan panelis lebih menyukai sampel F4 dibandingkan sampel yang lainnya, dan sampel F1 adalah sampel yang paling tidak disukai panelis dibandingkan sampel yang lainnya.

\section{Karakeristik Mikrobiologis (Total bakteri Probiotik)}

Starter yang digunakan dalam pembuatan minuman sinbiotik ini memiliki jumlah bakteri $10^{8} \mathrm{cfu} / \mathrm{ml}$. Menurut SNI 2981-2009 jumlah bakteri starter minimal $10^{7} \mathrm{koloni} / \mathrm{g}$. Penelitian ini menggunakan campuran starter Lactobacillus acidophillus IFO 13951, Bifidobacterium longum ATCC 15707 dengan perbandingan 1:1. Hasil analisis statistik menunjukkan bahwa perbedaan konsentrasi tepung uwi putih kulit cokelat dan susu skim berbeda nyata $(\mathrm{P}<0,05)$. Tabel 3 menunjukkan jumlah bakteri starter yang digunakan dalam pembuatan minuman sinbiotik uwi putih kulit cokelat.

Tabel 3. Total Bakteri Probiotik pada Starter Minuman Sinbiotik

\begin{tabular}{lc}
\hline \multicolumn{1}{c}{ Jenis Bakteri } & $\begin{array}{c}\text { Total } \\
\text { Bakteri } \\
(\log \mathrm{cfu} / \mathrm{ml})\end{array}$ \\
\hline L. acidophillus IFO 13951 & 8,361 \\
B. longum ATCC 15707 & 8,396 \\
\hline
\end{tabular}

Berdasarkan data pada Tabel 1 untuk semua formulasi minuman sinbiotik uwi putih kulit cokelat mengalami peningkatan jumlah bakteri probiotik. Hal tersebut dikarenakan ketersediaan nutrisi yang dibutuhkan oleh bakteri asam laktat untuk melakukan metabolisme. Hasil penelitian tersebut sesuai dengan penelitian dari Nuraida, dkk (2008) bahwa prebiotik yang terkandung dalam ubi jalar mendukung pertumbuhan Lactobacillus dan Bifidobacteria hingga dapat bertahan sampai saluran pencernaan.

Total bakteri probiotik paling tinggi terdapat pada sampel F2 dengan formulasi 2,5\% tepung uwi putih kulit cokelat : 7,5\% susu skim, sedangkan total bakteri probiotik paling rendah terdapat pada sampel F5 dengan formulasi $10 \%$ tepung uwi putih kulit cokelat : $0 \%$ susu skim. Hasil tersebut sesuai dengan jumlah yang disyaratkan oleh FAO/WHO (2002) yaitu $10^{6}-10^{8} \mathrm{cfu} / \mathrm{ml}$ dan diharapkan dapat berkembang menjadi $10^{12}$ $\mathrm{cfu} / \mathrm{ml}$ di dalam kolon. Jumlah tersebut juga 
sesuai dengan yang disyaratkan oleh SNI 2981-2009 yaitu minimal $10^{7} \mathrm{cfu} / \mathrm{ml}$ untuk starternya. Berdasarkan analisis derajat keasaman $(\mathrm{pH})$, kadar asam laktat, dan total bakteri probiotik dapat ditarik kesimpulan bahwa nilai $\mathrm{pH}$ berbanding terbalik dengan kadar asam laktat dan kadar asam laktat berbanding lurus dengan total bakteri probiotik. Dimana semakin rendah nilai $\mathrm{pH}$ maka kadar asam laktat semakin besar dan total bakteri probiotik akan semakin besar pula.

\section{KESIMPULAN}

Perbedaan konsentrasi tepung uwi putih kulit cokelat memberikan pengaruh terhadap karakteristik mutu minuman sinbiotik yang meliputi nilai $\mathrm{pH}$, kadar asam laktat dan nilai viskositas minuman sinbiotik. Nilai $\mathrm{pH}$ terendah $(3,68)$ dan kadar asam laktat tertinggi $(0,60)$ didapatkan dari formulasi $2,5 \%$ tepung uwi putih kulit cokelat : $7,5 \%$ susu skim. Sedangkan viskositas terbesar (10,92 mPas) didapatkan dari formulasi $10 \%$ tepung uwi putih kulit cokelat : $0 \%$ susu skim.

Perbedaan konsentrasi tepung uwi putih kulit cokelat memberikan pengaruh terhadap karakteristik sensori minuman sinbiotik. Perbedaan konsentrasi tepung uwi putih kulit cokelat memberikan pengaruh terhadap total bakteri probiotik minuman sinbiotik. Total bakteri probiotik terbesar didapatkan dari formulasi 2,5\% tepung uwi putih kulit cokelat : 7,5\% susu skim sebesar 9,39 $\log \mathrm{cfu} / \mathrm{ml}$.

\section{DAFTAR PUSTAKA}

Ainovi, I. D. 2010. Skripsi: Pembuatan Minuman Sinbiotik Dari Ubi Jalar Ungu (Ipomoe batatas varietas Ayamurasaki) Menggunakan Lactobacillus casei. Universitas Pembangunan Nasional "Veteran" Jawa Timur. Surabaya.

Alinnor, I.J., and C. O. Akalezi. 2010. Proximate and Mineral Compositions of Dioscorea rotundata (White Yam) and Colocasia esculenta (White Cocoyam). Pakistan Journal of Nutrition 9 (10): 998-1001.
Badan Standarisasi Nasional (BSN). 2009.

SNI: Yoghurt. Badan Standarisasi Nasional. Indonesia.

deMan, J.M., 1999. Principles of food chemistry $3^{\text {rd }}$ edition. Aspen Publication, Gaithersburg, Maryland.

FAO/WHO. 2002. Guidelines For The Evaluation of Probiotics in Food. Report of Joint FAO/WHO Working Group on Drafting Guidelines for The Evaluation of Probiotics in Food. Ontario. Canada.

Fardiaz, S. 1993. Analisis Mikrobiologi Pangan. Raja Grafindo. Jakarta.

Groff, J. L. and S. S. Gropper. 2000. Advanced Nutrition and Human Metabolism. Third Edition. Wadsworth. USA.

Hadiwiyoto, S. 1994. Teori dan Prosedur Pengujian Mutu Susu dan Hasil Olahannya. Agritech. Yogyakarta.

Kartika. B, P. Hastuti dan W. Supartono. 1988. Pedoman Uji Inderawi Bahan Pangan. PAU Pangan dan Gizi UGM. Yogyakarta.

Loo, J. V. 2006. Inulin-type Frutans as Prebiotis. Dalam Gibson, G.R. and R.A. Rastall (Edt). 2006. Prebiotis: Development and Application. John Wiley and Sons Ltd. England.

Ma'rifah, U. 2008. Skripsi: Pengaruh Penambahan Pati Singkong Modifikasi Ikat Silang dan Bakteri Asam Laktat Kandidat Probiotik Terhadap Mutu Yoghurt. Institut Pertanian Bogor. Bogor.

Mcanuff, M. A., F. O. Omoruyi, A. SoteloLo'Pez, and H. N. Asemota. 2005. Proximate Analysis and Some Antinutritional Factor Constituents in Selected Varieties of Jamaican Yams (Dioscorea and Rajana spp.). Springer: Plant Foods for Human Nutrition 60: 93-98, 2005.

Nuraida, L., Hana, S. R. Dwiari., dan D. N. Faridah. 2008. Pengujian Sifat Prebiotik Dan Sinbiotik Produk Olahan Ubi Jalar Secara In Vivo. Jurnal Teknologi dan Indudtri Pangan 19 (2). 
Nurdin, S. U dan S. Rizal. 2008. Optimasi Proses Produksi Minuman Sinbiotik dari Cincau Hijau (Premna oblongifolia Merr.) Sebagai Minuman Fungsional. Universitas Lampung. Lampung.

Pompei, A., L. Cordisco, S. Raimondi, A. Amaretti, and U. M. Pagnoni. 2008. Invitro Comparation of The Prebiotic Effect of Two Inulin-Type Fructans. Aerobe 14 (2009), 280-286.

Praja, D. I. 2011. The Miracle of Probiotics. Diva Press. Yogyakarta.

Roberfroid. M. B. 2005. Introducing Inulintype Fructans. British Journal of Nutrition (2005), 93, Suppl. 1, S13-S25.

Rosa, N. 2010. Pengaruh Penambahan Umbi Garut (Maranta Arundinaceae L) dalam Bentuk Tepung dan Pati Sebagai Prebiotik pada Yoghurt Sebagai Produk Sinbiotik Terhadap Daya Hambat Bakteri Escherichia Coli. Skripsi S1 Program Studi Ilmu Gizi Universitas Diponegoro. Semarang.

Sardesai, V. M. 2003. Introduction to Clinical Nutrition. Ed ke-2. Marcel. USA.

Slamet, A. 2010. Pengaruh Perlakuan Pendahuluan pada Pembuatan Tepung Ganyong (Canna edulis) Terhadap Sifat
Fisik dan Amilografi Tepung yang Dihasilkan. Jurnal AGROINTEK Vol 4, No. 2 Agustus 2010.

Suhardi. 1991. Kimia dan Teknologi Protein. PAU Pangan dan Gizi UGM. Yogyakarta.

Umam, M. F., R. Utami, dan E. Widowati. 2012. Kajian Karakteristik Minuman Sinbiotik Pisang Kepok (Musa paradisiaca forma typical) dengan Menggunakan Starter Lactobacillus acidophillus IFO 13951 dan Bifidobacterium longum ATCC 15707. Jurnal Teknosains Pangan Vol 1 No 1 Oktober 2012.

Widiyowati, I. I. 2007. Pengaruh Lama Perendaman dan Kadar Natrium Metabisulfit dalam Larutan Perendaman pada Potongan Ubi Jalar Kuning (Ipomoea batatas (L.) Lamb) Terhadap Kualitas Tepung yang Dihasilkan. Jurnal Teknologi Pertanian 2(2): 55-58, Maret 2007.

Yuniar, D. P. 2010. Karakteristik Beberapa Umbi Uwi (Dioscorea spp.) dan Kajian Potensi Kadar Inulinnya. Skripsi S1 Fakultas Teknologi Industri Universitas Pembangunan Nasional "Veteran". Surabaya. 